\title{
7 IHE STATUS AND THE FUTURE OF BALTIC STATES AND ROMANIA IN 1 THE STRATEGY OF WESTERN ALLIES IN THE EARLY YEARS OF THE SECOND WORLD WAR: A COMPARATIVE VIEW
}

\section{Ramojus Kraujelis}

Vilnius University, Faculty of History, E-mail: Ramojus.Kraujelis@if.vu.lt

This paper has been presented at the First International Conference on Nordic and Baltic Studies in Romania: Romania and Lithuania in the Interwar International Relations: Bonds, Intersections and Encounters hosted by the Romanian Association for Baltic and Nordic Studies, Târgoviste, May 19-21, 2010.

\begin{abstract}
:
The fate of Lithuania and Romania as well as future of the whole Central and Eastern European region was determined in the years of the Second World War. The common origin of their tragic and painful history was the MolotovRibbentrop Pact - the secret deal between Soviet Union and Nazi Germany, which divided Central and Eastern Europe between two totalitarian regimes. In June 1940 the three Baltic States and a part of Romania were directly occupied and annexed by the Soviet Union. The main objective of this paper is to identify, analyze and compare the attitudes of the United States and Great Britain with respect to the annexation of the Baltic States and the Romania territory and discussed the post-war future reserved to them. During the early years of the Second Word War (1940-1942) few interesting international discussions about possible post-war arrangement plans existed. The analysis of the Western attitude would enable us to give answers to certain questions: What could have been done by the Western states for the benefit of Central and Eastern European region; what have they, in fact, done and what did they avoid doing? The year 1943 witnessed the consolidation of the Western attitude with regard to Soviet Union's western borders, which resulted in the fundamental fact that Moscow did not intend to retract its interests in the Baltic States, Eastern Poland, North Bucovina and Bessarabia while the West did not intend to fight for these territories. Considering the fact that at the Teheran conference (1943) the Western states agreed upon turning the Baltic states into a Soviet interest sphere, the United States and Britain entered the Yalta conference (1945) with no illusions as to the fate of Central and Eastern Europe in general.
\end{abstract}


The Status and the future of Baltic States and Romania in the strategy of Western Allies in the early years of the Second World War: A comparative view

\begin{abstract}
Rezumat:
Soarta Lituaniei şi a României, ca şi viitorul întregii Europe Centrale şi de Răsărit, a fost hotărâtă în anii celui de-al Doilea Război Mondial. Cauza comună a acestei istorii tragice şi dureroase a fost Pactul Molotov-Ribbentrop şi anexa sa secretă - ințelegerea dintre Uniunea Sovietică şi Germania nazistă care a pus capăt păcii din perioada interbelică şi a împărțit Europa Centrală şi de Răsărit intre două regimuri totalitare. In iunie 1940 cele trei State baltice, precum şi o parte a României, au fost ocupate şi anexate în mod direct de Uniunea Sovietică. Principalul obiectiv al acestui articol este identificarea, analiza şi compararea atitudinilor Statelor Unite şi ale Marii Britanii - acele puteri occidentale care reprezentau punctul de vedere al democrațiilor occidentale şi abordau viitorul postbelic - cu privire la anexarea Țărilor baltice şi a teritoriului românesc. In primii ani ai celui de-al Doilea Război Mondial (1940-1942) au existat puține discuții interesante cu privire la aranjamentele postbelice. Analiza atitudinii occidentale ne va permite să dăm răspunsuri la câteva întrebări: ce ar fi putut fi făcut de statele occidentale în beneficiul regiunii Europei Centrale şi Răsăritene?; ce au făcut acestea în realitate şi ce au evitat să facă? Anul 1943 a fost martorul consolidării atitudinii occidentale cu privire la frontierele occidentale ale Uniunii Sovietice, ceea ce a avut ca efect următoarea atitudine fundamentală clară şi expresă: Uniunea Sovietică nu intenționa să-şi retracteze interesul său în ceea ce priveşte Tările baltice, Polonia de est, Bucovina de nord şi Basarabia, $\hat{\imath}$ vreme ce Vestul nu intenționa să lupte pentru aceste teritorii. Având $\hat{\imath}$ vedere faptul că $\hat{\imath}$ cadrul Conferinței de la Teheran (1943) statele occidentale au atribuit Țările baltice sferei de interes sovietice, Statele Unite şi Marea Britanie au mers la Conferința de la Yalta (1945) fără a-şi face iluzii cu privire la soarta Europei Centrale şi de Răsărit, în general.
\end{abstract}

Keywords: international politics, the Second World War, Lithuania, Romania, Baltic states, Great Powers

\title{
The Twilight of Interwar Peace Period
}

The political development of Europe between the two world wars was essentially influenced and conditioned by several key factors. First, the political system, formed as the result of the decisions of the Versailles Peace Treaty, with the League of Nations at its core. Second, the geopoliticaleconomic interests and the cultural-ideological priorities of the large states, the Great Powers. Third, the ability or inability of the medium or small European states to assist the League of Nations and the large states into maintaining stability and peace. ${ }^{1}$

\footnotetext{
1 Algimantas Kasparavičius, "Shared destiny: The Lithuanian state and diplomacy between the Two World Wars," Lithuanian foreign policy review, 13-14 (2004). 48-49.
} 
The Status and the future of Baltic States and Romania in the strategy of Western Allies in the early years of the Second World War: A comparative view

The fate of Lithuania (as small state) and Romania (as medium state) as well as future of whole Central and Eastern European region was determined by the traditional power balance and geopolitical arguments. The geopolitical position of Central and Eastern Europe in the international system was rather complicated.

During all interwar period, Soviet Union and Germany were unsatisfied with the political system created in Europe by the Versailles Peace Conference. Primarily, Soviet and German revisionist goals were orientated towards neighbouring states Poland, Romania and Czechoslovakia, while they treated the existence of Lithuania and the other small Baltic states only as a sign and manifestation of their temporary military and political weakness in an unfavourable international balance of power. ${ }^{2}$ The geopolitical interests of Germany aimed at securing its spheres of influence across Central and Eastern Europe via the establishment of a system of German protectorates. Plans were made for the inclusion of the Baltic states into this ring of Germany-linked quasi-states (satellites). Soviet Russia viewed the Baltic countries as a bridgehead for the expansion of the world socialist revolution to the West. Eventually, the attitude of the Soviets changed - the Baltic States were seen as an important buffer against the capitalist threat.

During the interwar period, the Baltic States were rather weak to perform any constant geopolitical function because destructive ethnonationalism prevented their elites to undertake designing of international politics even at the most elementary level. From a geopolitical point of view, the Western powers perceived all Central and Eastern European states as potential exchange objects in an eventual clash between the USSR and Germany. ${ }^{3}$ According to the French view, the new Baltic States together with some Central and Eastern European countries should have made up a belt of states from the North to the South of Europe that would separate and isolate Germany from Soviet Russia. The Great Britain (and partially the United States) projected the Baltic States both as a barrier and as a gateway to Russia. They sought not only to undercut German and Russian power, but also to create preconditions for them to accept liberal and democratic values. In this respect, the British model countered the

\footnotetext{
2 Algimantas Kasparavičius, The Ribbentrop-Molotov Pact and its Repercussions On Lithuania (Generalising Conclusions), (The International Commission for the Evaluation of the Crimes of the Nazi and Soviet Occupation Regimes in Lithuania. Research works database), http://www.komisija.lt/en/body.php?\&m=1194863084 (May 2, 2010).

3 Česlovas Laurinavičius, Egidijus Motieka and Nortautas Statkus, Baltijos valstybiu geopolitikos bruožai. XX amžius (Vilnius: LII leidykla, 2005), 407-408.
} 
The Status and the future of Baltic States and Romania in the strategy of Western Allies in the early years of the Second World War: A comparative view

French one and as such, it undermined the potential of the Baltic States to perform the function of a geopolitical gateway.

Following the Nazi Germany's Anschluss of Austria in March 1938 and the occupation of Czechoslovakia in the middle of March 1939 rumours spread that Baltic States, Poland and Romania were to be the next in line. First loss of Lithuania was Klaipeda, her only seaport. On March 22, 1939 Germany tore away Klaipeda from Lithuania while signatories of Klaipeda Convention (the Great Britain, France, Italy and Japan) remained discreetly silent. ${ }^{4}$ These issues confirmed that Nazi Germany was aiming for much more than the leaders of Western democratic countries could offer, but no one had any ideas on how to stop it.

In late March 1939 and mid-April, the British Prime Minister announced the famous guarantees of Poland and Romania's sovereignty. Although these guarantees extended to state sovereignty, they did not contain any references to the territorial integrity of the states. The Soviets were asked to provide similar guarantees. ${ }^{5}$ These unilateral guarantees rather than serving their security created freedom of manoeuvres to Joseph Stalin and the Soviet Union. In the spring of 1939, Stalin agreed to open negotiations with Great Britain and France. On April 17, 1939, the Soviets proposed that the Soviet Union, Great Britain and France enter into a pact of mutual assistance. The Soviets raised demands for at least the role of a caretaker in Central and Eastern Europe. Under the pretext of efficient fight against the aggressor, Moscow asked for the right of intervention.

As a proof of such intentions on March 28, 1939 the USSR handed in to Latvia and Estonia notes, which in a threatening way conveyed the intentions to protect its interests at the Baltic Sea shores. These notes confirm that the Soviet Union treated at least two of the Baltic states Estonia and Latvia - as the sphere of its national interests.

As regards Romania's international situation at this time, the main Soviet point of interest here was also territorial. Throughout the interwar period, Soviet Union had never recognized Bessarabia as a legitimate part of Romania and actively engaged in attempts to undermine this country by

\footnotetext{
4 Lietuvos užsienio reikalu ministrai 1918-1940 (Kaunas: Šviesa, 1999), 351-354; John Hiden, "Introduction: Baltic Security problems between the two World Wars", in The Baltic and the Outbreak of Second World War (New York: Cambridge University Press. 1992), 14-15.

5 Winston Churchill, The Second World War, Vol. I: The Gathering Storm (Boston: Houghton Mifflin Co. 1948), 322.
} 
The Status and the future of Baltic States and Romania in the strategy of Western Allies in the early years of the Second World War: A comparative view

nurturing diplomatic disputes with the government in Bucharest over this territory. ${ }^{6}$

According to the British perspective, the three European Great Powers, with Poland's help if possible, were to guarantee those states in Central and Eastern Europe which lay under the threat of German aggression. Nevertheless, according to Winston Churchill's view, the biggest problem in 1939 was that "Poland, Romania, Finland, and the three Baltic States did not know whether it was German aggression or Russian rescue that they dreaded more. It was this hideous choice that paralysed British and French policy."7 The negotiations reached a seemingly unbreakable deadlock. The Polish and Romanian Governments, while accepting the British guarantee, were not prepared to accept a similar undertaking in the same form from the Soviet Government. A similar attitude prevailed in the Baltic States. The Soviet Government made it clear that they would only adhere to a pact of mutual assistance if Finland and the Baltic States were included in a general guarantee.

The modern Russian historiography upholds the position that the USSR aimed at stating and defending their geostrategical interests in the negotiations with Western states, but they did not meet with understanding from their partners. The Soviets had tried to conclude pacts with the West, which never materialized.

At the end of June 1939, with Britain and France rejecting Soviet ambition to treat its north-eastern neighbours as an object of international relations, the secret Russian-German negotiations took a more specific shape. On July 22, 1939, the newspapers in Moscow announced that formal economic negotiations between the Soviet Union and Germany had been resumed. The negotiations with Germany and the Nazi-Soviet Nonaggression Pact of August 1939 created the opportunity for the Soviet Union to recover the western territories the Russian Empire had lost at the end of the First World War. ${ }^{8}$

6 Cristina Petrescu, "Contrasting/Conflicting Identities. Bessarabians, Romanians, Moldovans," in Nation-Building and Contested Identities. Romanian \& Hungarian Case Studies, eds. Balazs Trencsenyi et al. (Budapest \& Bucharest: Regio Books \& Polirom, 2001), 170.

${ }^{7}$ Churchill 1948, 325.

8 Christopher D. O'Sullivan, Sumner Welles, Postwar Planning, and the Quest for a New World Order, 1937-1943 (New York: Columbia University Press, 2008), 33. 
The Status and the future of Baltic States and Romania in the strategy of Western Allies in the early years of the Second World War: A comparative view

It become clear that Lithuania, like the other countries of Central and Eastern Europe, would not be allowed the luxury of solving its own problems: their fate would be determined by powerful outside forces. ${ }^{9}$

The provisions of the August 23 and September 28 secret protocols of the Ribbentrop-Molotov Pact will soon be enforced upon the Baltic States. After the invasion of Poland, in September-October 1939 the Soviet Union forced Estonia, Latvia and Lithuania to conclude Mutual Assistance Pacts which officially entitled the Red Army to set up military bases on the territories of these countries. Only Finland tried to resist to similar demands and consequently the Soviet Union attacked Finland thus starting the Winter War in November 1939. The war ended with territorial losses in March 1940, but Finland kept its independence. While in the first half of June 1940 the German troops were advancing towards Paris, the scope of Soviet claims on the Baltic States was rapidly extending. The Soviet Union accused Lithuania of breaking the agreement, and on June 14 Moscow submitted an ultimatum to Kaunas requesting to set up a pro-Soviet government in Lithuania and to allow an unlimited contingent of Russian troops to enter Lithuania. On June 15 Lithuania, having no other choice, accepted the terms of the Soviet ultimatum. On the same day, the Soviet Red Army completed the occupation of Lithuania and mounted its Sovietisation program. The following day, similar Soviet ultimatums were handed in to Estonia and Latvia, and on June 17 the two countries were fully occupied, as well. ${ }^{10}$.

Bearing the marks of the international system which resulted into the Baltic States loosing their independence, Romania also lost territories both in the east and the west. The Soviet Union claimed northern Bucovina and Bessarabia and the Hungarians claimed Transylvania. Following the same scenario applied to the Baltic States two weeks later, after receiving an ultimatum from the Soviet Union on June 26, Romania ceded Bessarabia and Northern Bucovina.

\section{The international reaction to the territorial changes in $\mathbf{1 9 4 0}$}

Initially, the reaction of the Western states towards the occupation and incorporation of the Baltic States into the Soviet Union of June 1940 - June 1941 can be regarded as ambiguous. The neighbouring Sweden and Nazi

\footnotetext{
9 Saulius Sužiedelis “Thoughts on Lithuania's Shadows of the Past: a Historical Essay on the Legacy of War", Vilnius. Magazine of the Lithuanian Writers' Union (Summer 1999): 179.

10 Полпреды сообщают... : Сб. документов об отномениях СССР с Латвией, Литвой и Эстонией: авг. 1939 г.-авг. 1940 г. (Москва : Междунар. отношения, 1990), 334-335.
} 
The Status and the future of Baltic States and Romania in the strategy of Western Allies in the early years of the Second World War: A comparative view

Germany were the first to take steps towards recognizing the incorporation of the Baltic States into the USSR. Interestingly, many European governments that were involved in the Second World War failed (or maybe were not interested) to express their own position regarding territorial changes in Europe. ${ }^{11}$

Germany needed Romania as a partner for the oil resources badly needed by its war machine, and for this reason it desired to establish closer ties with Romania. At the same time, the Romanian Government publicly declared on July 1 that they had renounced the Anglo-French guarantees. ${ }^{12}$

The Great Powers were well informed about the situation and the moods in the Baltic States and Romania. This is confirmed by the published diplomatic and other official records. ${ }^{13}$ Among the Great Western powers, the initial USA reaction in 1940-1942 could be termed as mostly "pro Baltic", while Great Britain followed a more pragmatic policy in respect to the Baltic States and the territorial changes in Europe. The British politicians saw the need for an agreement with the Soviet Union after the calamity of France's defeat. There is certainly a faint echo of this attitude in the record of the War Cabinet meeting of June 17, where Lord Halifax presented Soviet actions as a strengthening of Soviet defences against Germany. ${ }^{14}$

The key declaration of United States regarding Baltic States was the statement by the Acting State Secretary Sumner Welles of July 23: "During

\footnotetext{
11 From Lithuanian archival sources it is not possible to identify the position of Romania and Central and East European countries. Romania, Hungary and Bulgaria failed to express their official position regarding the occupation and incorporation of the Baltic States. Only in the 50 's the pro-Soviet governments have officially accepted official Soviet accounts of true "people's revolutions" in the Baltic nations in the summer of 1940. In 1958, bilateral protocols were signed by the Soviet Union and Bulgaria (January 18), Romania (March 7), Hungary (March 14), and Czechoslovakia (June 30), regulating the settlement of mutual claims concerning Lithuania, Latvia and Estonia. See more details in: William J.H. Hough, "The Annexation of the Baltic States and its Effect on the Development of Law Prohibiting Forcible Seizure of Territory", New York School Journal of International and Comparative Law 2 (1985), 437-438.

12 “Great Britain and Rumania” (HC Deb July 17, 1940 vol. 363, c. 187), http:/ / hansard.millbanksystems.com/commons/1940/jul/17/great-britain-andrumania\#S5CV0363P0_19400717_HOC_6 (April 20,2010$)$.

13 For example, there are 85 references related to Romanian issues and about 30 references regarding the Baltic States in the British parliament's transcript of 1940. See "Historic Hansard official reports of proceedings of both the House of Commons and the House of Lords", http://hansard.millbanksystems.com/sittings/1940 (April 20 , 2010).

14 John Hiden, "British Policy Towards the Baltic States: 1939-1945", Lithuanian historical studies 9 (2004), 79.
} 
The Status and the future of Baltic States and Romania in the strategy of Western Allies in the early years of the Second World War: A comparative view

these past few days the devious process whereunder the political independence and territorial integrity of the three small Baltic republics Estonia, Latvia, and Lithuania - were to be deliberately annihilated by one of their more powerful neighbors, have been rapidly drawing to their conclusion. From the day when the peoples of these republics first gained their independent and democratic form of government the people of the United States have watched their admirable progress in self-government with deep and sympathetic interest... The people of the United States are opposed to predatory activities no matter whether they are carried on by the use of force or by the threat of force." 15

The United States officially announced to the global community that nonrecognition policy ${ }^{16}$ should be applied regarding the occupation of the Baltic States. It means that the same nonrecognition standard would be applied to Soviet Union as it had been applied to Japan, Germany and Italy.

On July 26, there was important statement of British authorities on the Baltic States. In the Cabinet, British Foreign Secretary Lord Halifax said that the annexation of Baltic States had taken place in the "course of the war and there was no certainty that it would be permanent."17

The most important declaration made by the British Prime minister Winston Churchill was related to the general political situation in Eastern Europe and could be applied both to Baltic states as well as Romania and Poland. On September 5, Churchill declared in an address to the House of Commons: "We do not propose to recognize any territorial changes which take place during the war, unless they take place with the free consent and goodwill of the parties concerned."18

\footnotetext{
15 "Statement by the Acting Secretary of State Sumner Welles on Baltic Republics, July 23, 1940", Department of State Bulletin 111. No. 57, July 27, 1940, 48.

16 It should be noted that the United States continued not to recognize the forcible annexation of Baltic States and maintained nonrecognition policy up to 1991, when the Baltic States finally restored their independence. The practical measures taken by the United States were consistent with this interpretation. The diplomatic and consular agencies of the Baltic Republics were allowed to continue their activities as representatives of Estonia, Latvia and Lithuania and steps were taken to protect Baltic assets in the United States. See more details at Lawrence Juda, “United States Non-recognition of the Soviet Union's Annexation of the Baltic States: Politics and Law", Journal of Baltic Studies 4 (1975): 272-290.

17 Edgar Anderson, "British Policy Toward the Baltic States 1940-1941," Journal of Baltic Studies 4 (1980), 328.

18 Richard Langworth, "Churchill and the Baltic, Part II: 1931-1950" (The Churchill Centre and Churchill Museum at the Cabinet War Rooms) http://www.winstonchurchill.org/support/the-churchill-centre/publications/finesthour/issues-37-72/no-53/853-churchill-and-the-baltic-part-ii-1931-1950 (April 20, 2010).
} 
The Status and the future of Baltic States and Romania in the strategy of Western Allies in the early years of the Second World War: A comparative view

It is appropriate to make a brief mention of Soviet explanation of the territorial changes. The best representation of the Soviet position and its justification came as a spectacular episode of diplomatic conversations. On August 16, the Soviet Ambassador, Ivan Maisky, made a request to British Foreign Secretary Lord Halifax for the termination of the Baltic Legations in Great Britain. Halifax refused to acquiesce to I. Maisky's request and denounced the Soviet Union's aggression in the Baltic region. Ambassador Maisky responded by citing the allegorical story of the Siberian peasant Ivan. During Ivan's illness, his neighbours came and stole his property. After his recovery, Ivan forcibly took back that which had been stolen from him. "So now, Lord Halifax, who was the aggressor in your opinion, the peasant Ivan or his neighbors?"19

Britain and its allies had their own positive concept of how a greater part of the continent of Europe should be organized on the principles of freedom and equality. At the time, Great Britain favoured a more general idea of the reconstruction of post-war European regional federation/confederation, which could serve as a barrier between Germany and the Soviet Union. The first Polish-Czechoslovak émigré governments' declaration was issued soon on November 11. For solving the problem of a Central European Federation, the Polish government was interested in taking in Lithuania, Hungary and possibly Romania, in addition to Czechoslovakia. ${ }^{20}$

Two months before the beginning of the German invasion of the USSR, the new British Foreign Secretary Anthony Eden had raised the possibility of recognizing Stalin's territorial acquisitions obtained in 1939-1940. Churchill, Attlee, and other British officials were strongly resistant to any concessions, and for a time London refused to recognize the USSR's new boundaries.

On November 23, Romania signed the Tripartite Pact and joined Germany as an ally. These political decisions were influence by the Romanian desire for protection against the Soviet Union. Romania entered the Second World War in June 1941, declaring war to the Soviet Union in order to recover Bessarabia and Northern Bucovina.

From this point we can see that the common dominant in Lithuanian and Romanian issues was non-recognition of territorial changes.

\footnotetext{
19 Ivan Maisky, Memoirs of a Soviet ambassador, the War 1939-43 (London: Hutchinson, 1967), 139-140.

${ }^{20}$ Tadeusz Kisielewski, "Federalist Plans in Central and Eastern Europe and the Question of the Baltic States in the Context of Polish Politics during World War II," Lithuanian Historical Studies 9 (2004), 21, 28.
} 
The Status and the future of Baltic States and Romania in the strategy of Western Allies in the early years of the Second World War: A comparative view

\section{The early post-war planning 1941-1942}

As in June 1941 Nazi Germany advanced eastward, the United States, Great Britain and USSR now finally had a common enemy. Under these circumstances, the leaders of Great Britain, the Soviet Union and the United States of America, known as "The Big Three", started cooperation talks. The Soviet Union was able to attract sympathy and support from the West, with the unintended result that the Soviet aggression of 1939-1940 was deemphasized. Nevertheless, hopes for the suppressed nations aroused with the Atlantic Charter, signed by US President Roosevelt and British Prime Minister Winston Churchill on August 14. The document was based on the principle of self-determination as regards the European territorial changes and forms of government. The Soviet Union also announced the acceptance of the charter's principles, but as the tide of the war shifted, the moral-idealistic principles of the Atlantic Charter could practically do little on behalf of Central and Eastern Europe. The attitude of the Great Powers towards this region started to be based on practical realities. It should be mentioned that the ultimate role on the worldwide stage was played not by the legal or moral arguments, but the international political coexistence.

From summer 1941, Romania's situation started to differ from the Baltic States: the first and main difference was that Romania was still independent and ruled by its own government, and even some lost territories were taken back. Another factor that influenced attitudes of Western powers, Romania was treated Nazi German ally and thus as a hostile country. According to the British position, Romania was regarded as an enemy state whose interests could easily be sacrificed to Moscow in order to speed Germany's defeat and to use diplomatic concessions from Stalin on other issues. The British Foreign Secretary Eden rejected the idea that Great Britain was politically and morally responsible for guaranteeing Romania's territory: "Romania rejected the British guarantee and chose to collaborate with Germany. Britain subsequently declared war on Romania and does not feel bound by obligations existing under its former guarantee." 21

During the early years of the Second Word War there were few interesting international discussions about possible post-war arrangement plans. It must be mentioned that the future of Baltic States and Romania

21 George Cioranescu, "The problem of Bessarabia and Northern Bucovina during World War II (Part II)", Radio Free Europe Research, December 2, 1981, Open Society Archives (OSA). RAD Background Report/329/ 53-3-12, 11-12. 
The Status and the future of Baltic States and Romania in the strategy of Western Allies in the early years of the Second World War: A comparative view

were regarded and discussed according to a similar pattern. The issue of the Baltic States was seen as a constituent part of considerations regarding the complex problems raised by the war. The position regarding Central an Eastern Europe was based on a mixture of balanced pragmatism and expedience criteria.

In December 1941 Stalin raised the issue of British recognition of the Soviet Union's 1941 frontiers at his second meeting with British Foreign Secretary Eden. ${ }^{22}$ In response to this proposal, Churchill on January 8, 1942 wrote to Eden: "We have never recognized the 1941 frontiers of Russian except de facto. They were acquired by acts of aggression in shameful collusion with Hitler. The transfer of the Baltic States to Soviet Russia against their will would be contrary to all the principles for which we are fighting this war and would dishonour our cause. This also applies to Bessarabia and to Northern Bukovina, and in a lesser degree to Finland, which I gather it is not intended wholly to subjugate and absorb. Russia could, upon strategical grounds, make a case for the approaches to Leningrad... Strategical security may be invoked at certain points on the frontiers of Bukhovina [sic] or Bessarabia. In these cases the population would have to be offered evacuation and compensation if they desired it. In all other cases transference of territory must be regulated after the war is over by freely and fairly conducted plebiscites ..." 23

The negotiations in 1942 over the Anglo-Soviet treaty of alliance witnessed a fight between East and West over the Baltic States and other territories that were incorporated in the Soviet Union in 1940. The British position in these discussions is again characterized by pragmatism. Through the Anglo-Soviet draft proposal, Great Britain was ready to grant recognition to Soviet Union frontiers analogous to those obtained under the Ribbentrop-Molotov Pact of 1939, thus sacrificing the vital interests of a considerable part of Eastern Europe. Largely due to United States pressure, the treaty was signed in May 1942, with no provision of recognition of the Soviet frontiers. In these negotiations of 1942, the Baltic States were only bargaining counters in relations with Soviet Union.

One of the most interesting discussion about the future of Central and Eastern Europe arose in 1942-1943 in the United States Department of State. The Advisory Committee on Post-War Foreign Policy was created on

\footnotetext{
22 Llewellyn Woodward, British foreign policy in the Second World War, vol. II (London, 1971), 226-233.

${ }^{23}$ Winston Churchill, The Second World War. Vol III. The Grand Alliance (Boston: Houghton Mifflin Co. 1950), 694.
} 
The Status and the future of Baltic States and Romania in the strategy of Western Allies in the early years of the Second World War: A comparative view

February 12, 1942, to prepare recommendations for President Roosevelt on post-war foreign policy. The chairman of the committee was State Secretary Cordell Hull and vice-chairman, Under Secretary of State Sumner Welles. In fact, Welles was one of the chief administrative officers of United States foreign policy. In spring 1942, Welles first offered a detailed outline of his vision of so-called East European Federation. It must be mentioned that the issue of the Baltic States was never discussed separately in this Committee - the status of Baltic States rose as a constituent part of considerations of complex problems. The future of Baltic States and Romania were seen and discussed as part of the same common block.

According to Welles' vision, an union or federation among Austria, Czechoslovakia, Hungary, Poland, Romania, Yugoslavia, Albania, Bulgaria, the Baltic States, and possibly Finland, Greece, and Turkey might successfully check and contain both Germany and the Soviet Union and promote economic union and stability in the region. The committee subsequently discussed specific aspects, such as customs and monetary union as well as the elimination of borders. The members should seek to organize the nations in the region to provide a "strong and stable counterweight and buffer to Germany and Russia" so that the area would no longer "be a field for the intrigues and manoeuvres" of Berlin and Moscow. ${ }^{24}$

The committee considered that the Russians might dominate the nations of Czechoslovakia, Yugoslavia, and Bulgaria, but Russian influence would be balanced within a federation by including "anti-Russian" nations such as Poland, Hungary, Austria, and Romania. The committee also supposed that the federation might even help facilitate the rebirth of the Baltic States as fully functioning, independent republics. Welles and the planners feared that if the Russians forcibly removed the Baltic region and Eastern Europe from post-war plans for a worldwide liberal economic system, the European reconstruction would be much more difficult and the efforts at creating a new order would be dealt a serious setback.

The members of committee acknowledged that active American participation in an East European Federation would represent a "departure from old conceptions" about America's vital interest. It was hoped that the creation of a federation would prove advantageous to the economic and security interests of the United States, not only through the promotion of free trade, but also by checking the territorial, political, and economic

24 Minutes of the Advisory Committee on Post-War Policy, May 2, 1942, National Archives, Notter files, box 55, RG 59; O'Sullivan, 42. 
The Status and the future of Baltic States and Romania in the strategy of Western Allies in the early years of the Second World War: A comparative view

aspirations of Germany, the Soviet Union, and Great Britain. Welles explained that the nations of the region might be bound together by "Articles of Confederation" which would include guarantees of individual rights and personal freedoms. The political structure of the federation would feature an American-style judicial system, a federal diet, customs union, and an intra-regional military force.

The plans about a possible post-war federation were discussed wider in Europe. It is worth mentioning that the head of the Polish government in London, General Wladyslaw Sikorski, during the meetings held in Washington and London in 1942 supported the idea of a federation and voiced the argument that "the annexation of Bucovina and Lithuania by the Soviet Union will deal a blow to the federation project, because cession of Bucovina and Lithuania would put Poland squarely in the Soviet pincers from north and south..." 25 But by early 1943, following the Red Army's success at Stalingrad, it became apparent that the Soviet Union might oppose all efforts to construct a federation.

\section{3 - year of the final decision}

The year 1943 witnessed the consolidation of the Western attitude with regard to Soviet demands to the pre-war frontiers. The Soviet victories in 1943 opened the way to Central and Eastern European region. The participation of the Soviet Union in the final stage of the Second World War was an essential benchmark, which influenced the changes of US attitudes toward the problem of the Baltic States in 1943. The United States has long infused morality and idealism into its foreign policy. In October 5, 1943, President Roosevelt spelled out his plans for the upcoming Teheran conference. Regarding Poland and the Baltic States, the President argued that, when he should meet Stalin, he intended to appeal to him on grounds of high morality. He would say to him that neither Britain nor U.S. would fight Russia over the Baltic States, but that in Russia's own interest it would be a good thing to hold a second plebiscite in the Baltic countries. ${ }^{26}$

When Hull returned from Moscow on November 15, he declared that the Baltic and Balkan States deserved the right of self-determination.

\footnotetext{
25 Foreign Relations of the United States (F.R.U.S). Diplomatic Papers 1944, Vol. IV, Europe (Washington: Government Printing Office, 1966), 124, 128.

${ }^{26}$ Richard A. Schnorf, "The Baltic States in U.S.-Soviet Relations. The year of doubts 19431946," Lituanus. Lithuanian Quarterly Journal of Arts and Sciences 12, No. 4 (1966): 59; Michail Miagkov, "SSSR ir JAV diskusija Baltijos valstybiu klausimu1941-1945 metais," in Lietuva Antrajame pasauliniame kare eds. Arvydas Anušauskas and Česlovas Laurinavičius (Vilnius: Lietuvos istorijos instituto leidykla, 2007), 159.
} 
The Status and the future of Baltic States and Romania in the strategy of Western Allies in the early years of the Second World War: A comparative view

According to him, each state, regardless of its size, was sovereign and equal. Despite such high minded pronouncements, the real State Department assessments regarding Moscow were pessimistic. When encountering this state of affairs, Jan Ciechanowski, the Polish ambassador to the U.S., in the eve of the Teheran conference surmised "that, as far as could then be ascertained, America and Britain had to sacrifice the three Baltic countries and half of Poland to Russia for the sake of understanding with the Soviets. ${ }^{27}$

The successful military actions of the Soviet Union guaranteed political predominance of the USSR in the meetings of "the Big Three". The main decisions on the future of the post-war Europe were made in conferences in Teheran and Yalta. The Soviet Union did not intend to retract its interests in Baltic States, Eastern Poland, North Bucovina and Bessarabia, while the West did not intend to fight for these territories.

At the Teheran conference (November 28-December 1) one of Roosevelt and Churchill's main concessions concerned post-war Poland. It was absolutely clear that if an agreement could be reached on Poland's eastern frontiers, Lithuania as well all other territories will be also reoccupied by the Soviet Union. ${ }^{28}$ The Teheran agreements on Polish eastern border in fact determined the fate and the future territory of Lithuania. The issues pertaining to the Baltic States was never raised again at the highest level.

It could be noted that at the same time that in Romania both Marshal Ion Antonescu and Iuliu Maniu, the head of democratic opposition and a prominent old politician, tried to pull Romania out of a war that had virtually been lost, while nevertheless maintaining Romania's sovereignty over Bessarabia and Northern Bucovina. ${ }^{29}$

In April 1944 the U.S. Department's Division of Southern European Affairs prepared a memorandum on Romania which stated that "the British and American governments might consider the desirability of reaffirming their expectation that Romania and the other Axis satellites should exist in future as independent [states] within reasonable frontiers... ... there is no indication that Moscow would permit

\footnotetext{
27 Cordell Hull, The Memoirs of Cordell Hull (New York: Macmillan, 1948), 1266; Jan Ciechanowski, Defeat in Victory (New York: Doubleday \& Co, Garden City, 1947), 228.

28 F.R.U.S., Diplomatic Papers. The Conferences at Cairo and Teheran. 1943 (Washington: Government Printing Office, 1961), 594; Советский Союз на международных конференциях периода Великой Отечественной войны 1941-1945 г2. Том II. Тегеранская конференция руководителей трех союзных держав - СССР США и Великобритании (28 ноября - 1 декабря 1943 г.) Сборник документов (Москва, 1984), 151.

${ }^{29}$ Cioranescu, part III, 1.
} 
The Status and the future of Baltic States and Romania in the strategy of Western Allies in the early years of the Second World War: A comparative view

this question to be opened."30 Therefore the State Department also considered Bessarabia and Northern Bucovina virtually lost for Romania, taking a firmer stand only in case the Soviet Union would claim even more Romanian territory.

A few months later, on October 9, at Moscow Conference two leaders draw the infamous "percentages agreement" on the suggested influence of their states in Romania, Bulgaria, Greece, Hungary and Yugoslavia ${ }^{31}$ Thus, the U.S. and Britain entered the Yalta conference with no illusions as to the fate of the Baltic States in particular and Central and Eastern Europe in general. By February 1945, the position of the Red Army had already made the fate of Central and Eastern Europe a de facto reality.

These attitudes confirm my main proposition - the fate of Lithuania and Romania, as well as future of whole Central and Eastern European region was determined in the years of the Second World War as a consequence of traditional power balance and geopolitical arguments.

In the final years of the Second World War, the issue of the Baltic States did not occur on the list of the most important problems of the Western Great Powers' policy and was treated as an additional negotiating point. The policy of the West - not only in respect of the Baltic States, however, but of the states of the entire Central and Eastern European region remained weak.

\section{Epilogue...}

The final changes which symbolically ended of Second World War reached Romania and the other Central and Eastern European countries in 1989, but they were finalized in 1990-1991 for the three Baltic States. Quoting the President of the European Parliament Jerzy Buzek: "Today we are a reunited and integrated continent because we have learnt the lessons of the Second World War, and the pact that allowed it to happen." 32

\section{References:}

\section{A. Archives:}

\footnotetext{
30 Memorandum by the Division of Southern European Affairs, Washington, (no day) March 1944 in: F.R.U.S. 1944, 146.

31 Winston Churchill, The Second World War, Vol. VI: Triumph and Tragedy (Boston: Houghton Mifflin Co. 1953), 198, 204.

32 "Speech of the President of the European Parliament Jerzy Buzek for 70th Anniversary of the Molotov-Ribbentrop Pact", Brussels, October 14, 2009, http://www.eppresident.eu/view/en/press/speeches/sp-2009/sp-2009-October/speeches-2009-October5.html (April 15, 2010)
} 
The Status and the future of Baltic States and Romania in the strategy of Western Allies in the early years of the Second World War: A comparative view

Arhivele Diplomatice ale Ministerului Afacerilor Externe [The Diplomatic Archives of the Romanian Foreign Ministry]:

\section{B. Published documents:}

Department of State Bulletin. 111. No. 57, July 27, 1940.

Foreign Relations of the United States. Diplomatic Papers 1944. Vol. IV: Europe. Washington: Government Printing Office, 1966.

Foreign Relations of the United States. Diplomatic Papers. The Conferences at Cairo and Teheran. 1943. Washington: Government Printing Office, 1961.

\section{Diaries, memoirs:}

Churchill, Winston. The Second World War. Vol. I: The Gathering Storm. Boston: Houghton Mifflin Co, 1948.

Churchill, Winston. The Second World War. Vol III: The Grand Alliance. Boston: Houghton Mifflin Co., 1950.

Churchill, Winston. The Second World War. Vol. VI: Triumph and Tragedy. Boston: Houghton Mifflin Co, 1953.

Ciechanowski, Jan. Defeat in Victory. New York: Doubleday \& Co, Garden City, 1947.

Hull Cordell. The Memoirs of Cordell Hull. New York: Macmillan, 1948.

Maisky, Ivan. Memoirs of a Soviet ambassador, the War 1939-43. London: Hutchinson, 1967.

\section{Books and articles:}

Anderson, Edgar. "British Policy Toward the Baltic States 1940-1941." Journal of Baltic Studies XI, no. 4 (1980): p. 325-333.

Anušauskas, Arvydas, and Česlovas Laurinavičius. Lietuva Antrajame pasauliniame kare. Vilnius : Lietuvos istorijos instituto leidykla, 2007.

Cioranescu George. "The problem of Bessarabia and Northern Bucovina during World War II (Part I-II)". Radio Free Europe Research, December 2, 1981. Open Society Archives (OSA). RAD Background Report/329/ 53-3-12.

Hiden, John. "British Policy Towards the Baltic States: 1939-1945." Lithuanian historical studies 9 (2004): 75-87.

Hiden, John and Thomas Lane. The Baltic and the Outbreak of Second World War. New York: Cambridge University Press, 1992.

Hough William J.H. "The Annexation of the Baltic States and its Effect on the Development of Law Prohibiting Forcible Seizure of Territory". New York School Journal of International and Comparative Law 2 (1985): 390-470.

Juda, Lawrence. “United States Non-recognition of the Soviet Union's Annexation of the Baltic States: Politics and Law." Journal of Baltic Studies 4 (1975): 272-290.

Kasparavičius, Algimantas. "Shared destiny: The Lithuanian state and diplomacy between the Two World Wars". Lithuanian foreign policy review 13/14 (2004): 48-70. 
The Status and the future of Baltic States and Romania in the strategy of Western Allies in the early years of the Second World War: A comparative view

Kisielewski, Tadeusz. "Federalist Plans in Central and Eastern Europe and the Question of the Baltic States in the Context of Polish Politics during World War II." Lithuanian Historical Studies 9 (2004): 19-33.

Laurinavičius, Česlovas, Egidijus Motieka, and Nortautas Statkus. Baltijos valstybiu geopolitikos bruožai. XX amžius. Vilnius: LII leidykla, 2005.

Lietuvos užsienio reikalu ministrai 1918-1940. Kaunas: Šviesa, 1999.

O'Sullivan, Christopher D. Sumner Welles, Postwar Planning, and the Quest for a New World Order, 1937-1943. New York: Columbia University Press, 2008.

Petrescu, Cristina. "Contrasting/Conflicting Identities. Bessarabians, Romanians, Moldovans." In Nation-Building and Contested Identities. Romanian \& Hungarian Case Studies. Edited by Trencsenyi Balazs et al. Budapest \& Bucharest: Regio Books \& Polirom, 2001.

Полпреды сообщают... : Сб. документов об отношениях СССР с Латвией, Литвой и Эстонией: авг. 1939 г.-авг. 1940 г. Москва: Междунар. отношения, 1990.

Schnorf, Richard A. "The Baltic States in U.S.-Soviet Relations. The year of Doubts 1943-1946." Lituanus. Lithuanian Quarterly Journal of Arts and Sciences 12, No. 4 (1966).

Советский Союз на международных конференциях периода Великой Отечественной войны 1941-1945 гг. Том II. Тегеранская конференция руководителей трех союзных держав - СССР США и Великобритании (28 ноября - 1 декабря 1943 г.) Сборник документов. Москва, 1984.

Sužiedelis, Saulius. "Thoughts on Lithuania's Shadows of the Past: a Historical Essay on the Legacy of War." Vilnius. Magazine of the Lithuanian Writers' Union. Summer 1999. Woodward, Llewellyn. British foreign policy in the Second World War. Volume II. London. 1971.

\section{Internet:}

"Historic Hansard official reports of proceedings of both the House of Commons and the House of Lords". http://hansard.millbanksystems.com/sittings/1940 (accessed April 20,2010 ).

Kasparavičius, Algimantas. "The Ribbentrop-Molotov Pact and its Repercussions On Lithuania (Generalising Conclusions)". The International Commission for the Evaluation of the Crimes of the Nazi and Soviet Occupation Regimes in Lithuania. Research works database. http://www.komisija.lt/en/body.php?\&m=1194863084 (accessed May 2 , 2010).

Langworth, Richard. Churchill and the Baltic, Part II: 1931-1950. The Churchill Centre and Churchill Museum at the Cabinet War Rooms. http://www.winstonchurchill.org/support/the-churchillcentre/publications/finest-hour/issues-37-72/no-53/853-churchill-and-the-balticpart-ii-1931-1950 (accessed April 20, 2010).

"Speech of the President of the European Parliament Jerzy Buzek for 70th Anniversary of the Molotov-Ribbentrop Pact". Brussels, October 14, 2009. http://www.ep-president.eu/view/en/press/speeches/sp-2009/sp-2009October/speeches-2009-October-5.html. 
The Status and the future of Baltic States and Romania in the strategy of Western Allies in the early years of the Second World War: A comparative view 